\title{
Effect of the reaction medium on the immobilization of nutrients in hydrochars obtained using sugarcane industry residues
}

\author{
Camila Centurion Silva ${ }^{a}$, Camila Almeida Melo ${ }^{\mathrm{a}, *}$, Francisco Holanda Soares Junior ${ }^{\mathrm{b}}$, \\ Altair Benedito Moreira ${ }^{a}$, Odair Pastor Ferreira ${ }^{\text {b }}$, Márcia Cristina Bisinoti ${ }^{a}$ \\ a Instituto de Biociências, Letras e Ciências Exatas, UNESP, Univ Estadual Paulista, Campus São José do Rio Preto, Departamento de Química e Ciências Ambientais, Laboratório \\ de Estudos em Ciências Ambientais, Cristóvão Colombo, 2265, São José do Rio Preto, São Paulo State 15054-000, Brazil \\ ${ }^{\mathrm{b}}$ Laboratório de Materiais Funcionais Avançados (LaMFA), Departamento de Física, Universidade Federal do Ceará, P.0. Box 6030, Fortaleza, Ceará 60455-900, Brazil
}

\section{H I G H L I G H T S}

- HTC of sugarcane bagasse and vinasse immobilizes nutrients in the hydrochar.

- Increasing the temperature of the HTC, increases the immobilization of nutrients.

- The addition of acids, bases and salts influences the immobilization of nutrients.

\section{A R T I C L E I N F O}

\section{Article history:}

Received 26 December 2016

Received in revised form 29 March 2017

Accepted 1 April 2017

Available online 4 April 2017

\section{Keywords:}

Immobilization

Hydrothermal carbonization

Sugarcane bagasse

Vinasse
G R A P H I C A L A B S T R A C T

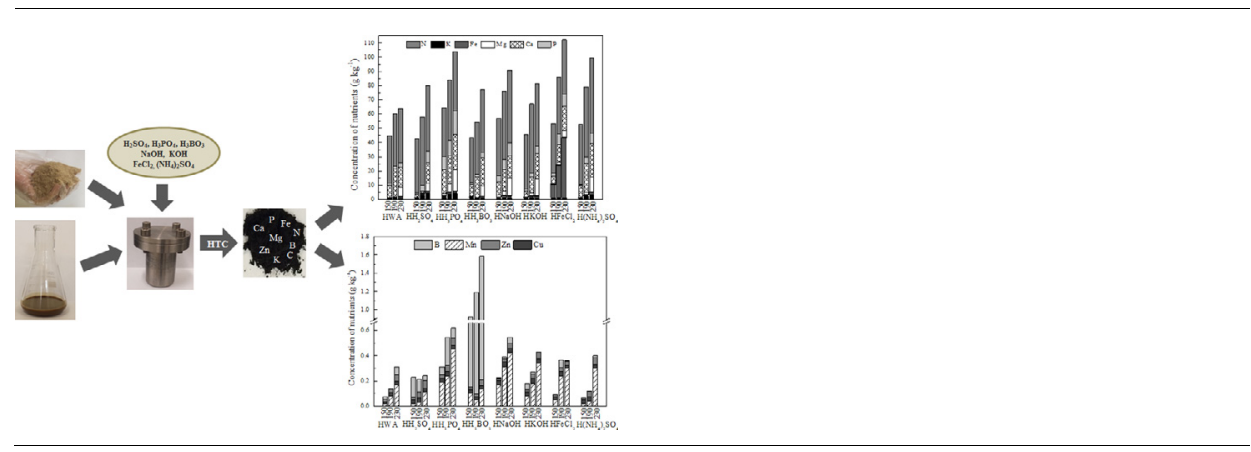

\begin{abstract}
A B S T R A C T
In this study, nutrients were immobilized on the hydrochars obtained by hydrothermal carbonization (HTC) of a vinasse and sugarcane bagasse mixture, in the presence of acid, base and salt additives at temperatures of 150,190 and $230^{\circ} \mathrm{C}$. The increase in temperature caused higher immobilization of $\mathrm{Ca}, \mathrm{Mg}, \mathrm{K}$, $\mathrm{N}, \mathrm{Cu}, \mathrm{Mn}, \mathrm{Zn}, \mathrm{B}, \mathrm{P}$ and $\mathrm{Fe}$ in all hydrochars produced. $\mathrm{H}_{3} \mathrm{PO}_{4}$ and $\mathrm{NaOH}$ immobilized higher amounts of $\mathrm{P}$, $\mathrm{Mg}$ and $\mathrm{Mn}$, while Ca was immobilized in higher quantities in the presence of $\mathrm{H}_{3} \mathrm{PO}_{4}$ and $\left(\mathrm{NH}_{4}\right)_{2} \mathrm{SO}_{4}$. The addition of $\mathrm{H}_{2} \mathrm{SO}_{4}, \mathrm{H}_{3} \mathrm{PO}_{4}$ and $\left(\mathrm{NH}_{4}\right)_{2} \mathrm{SO}_{4}$ was responsible for an increased immobilization of $\mathrm{P}, \mathrm{N}, \mathrm{Ca}, \mathrm{Mg}$ and $\mathrm{K}$. The immobilization of $\mathrm{B}$, not present in the starting raw material, was possible with the addition of $\mathrm{H}_{3} \mathrm{BO}_{3}$. The results showed that it is possible to alter the reaction medium to immobilize nutrients on hydrochars produced from vinasse and sugarcane bagasse, for agricultural applications.
\end{abstract}

(c) 2017 Elsevier Ltd. All rights reserved.

\section{Introduction}

Sugarcane is the most widely cultivated crop in subtropical countries, Brazil standing out as the largest producer, followed by India, China and Thailand. Worldwide, the total area planted

\footnotetext{
* Corresponding author at: Laboratório de Estudos em Ciências Ambientais, Departamento de Química e Ciências Ambientais, Universidade Estadual Paulista, Cristóvão Colombo, 2265, São José do Rio Preto, São Paulo State 15054-000, Brazil.

E-mail address: camila.sjrp@gmail.com (C.A. Melo).
}

with sugarcane is 26 million hectares, producing 1.83 billion tons. The main product is sugar (92\%), followed by ethanol and animal feed (FAO, 2016). However, in the ethanol production two residues are generated in large quantities: vinasse and sugarcane bagasse, which can cause serious damage to the environment, if improperly disposed of.

Vinasse is a liquid residue from the distillation of ethanol, generating 10 to 15 liters of vinasse for each liter of ethanol produced. Its composition varies according to the place where the sugarcane is produced. In general, the vinasse is acidic with a $\mathrm{pH}$ of 3.5-5.0, 
has high concentrations of organic matter $\left(40-110 \mathrm{~g} \mathrm{~L}^{-1}\right.$ total organic carbon), potassium (2-5 $\left.\mathrm{g} \mathrm{L}^{-1}\right)$, phosphorus (0.04-0.20 $\mathrm{g}$ $\mathrm{L}^{-1}$ ), nitrogen (0.1-1.2 $\mathrm{g} \mathrm{L}^{-1}$ ), sodium (350 $\left.\mathrm{mg} \mathrm{L}^{-1}\right)$, and other chemical elements such as $\mathrm{Ca}, \mathrm{Mg}, \mathrm{Cu}, \mathrm{Al}$ (Moraes et al., 2015; Wilkie et al., 2000). The main use of vinasse today is in fertiirrigation. However, several studies have warned about environmental problems resulting from this practice (Fuess and Garcia, 2014). Among these problems are salinization of soil, contamination of aquifers, reduction of alkalinity and loss of productivity (Brito et al., 2005, 2007; Lyra et al., 2003). With this in mind, other treatment suggestions have been made, such as the anaerobic digestion of vinasse for the production of biogas, concentration of vinasse by evaporation, energy production, protein production and animal feeding (Christofoletti et al., 2013).

The second residue generated by the sugarcane industry is sugarcane bagasse (300 kg for each ton of processed sugarcane). This is a fibrous material, consisting mainly of cellulose (26.6-54.3\%), hemicellulose (14.3-24.4\%) and lignin (22.7-29.7\%) (Loh et al., 2013). Since 2003, sugarcane bagasse has been burned to generate electricity. Despite the low environmental impact of its main use, other technologies have been developed within the context of biorefineries, such as the production of natural fiber, sweeteners, lactic acid, biopolymers, substrate to produce enzymes, biohydrogen, biobutanol, composites, organic acids, production of secondgeneration ethanol, among others (Ferreira-Leitão et al., 2010; Pessoa-Jr et al., 2005; Sindhu et al., 2016).

With population growth and subsequent increased demand for food, fertilizers are used to increase agricultural productivity (FAO, 2015). Most of the nutrients used in fertilizers are extracted from finite natural reserves, where extraction problems create environmental contamination and risks to the health of the workers, and also the extraction process is expensive and involves numerous steps (Othman and Al-Masri, 2007). In this context, the search for the manufacture of fertilizers from the reutilization of nutrients present in materials initially considered as waste, which impact the environment less, is of great interest. However, it is important to consider the permissible concentration limits of some heavy metals according to guidelines for soil application (EBC, 2015; IBI, 2015).

Recent research has proposed the use of biomass or residues from agribusiness (animal manures, wheat straw, sucroenergetic wastes and others) as raw materials for the immobilization, extraction or recovery of nutrients such as $\mathrm{P}, \mathrm{N}$ and $\mathrm{K}$ using hydrothermal carbonization (HTC) (Ekpo et al., 2016; Heilmann et al., 2014; Melo et al., 2016; Wiedner et al., 2013). HTC is considered to be an ecofriendly process, since it employs aqueous media, moderate temperatures $\left(150-350^{\circ} \mathrm{C}\right)$ and self-generated pressure, and produces a solid material called hydrochar (Kruse et al., 2013). Some authors have estimated the effect of the reaction medium at different temperatures and for different times, varying the $\mathrm{pH}$ and using additives, on the incorporation and recovery of nutrients from the HTC using different biomasses (Dai et al., 2015; Ekpo et al., 2016; Reza et al., 2016; Smith and Ross, 2016). Ekpo et al. (2016) demonstrated that increasing temperature, highest levels of $\mathrm{Ca}$ and $\mathrm{Mg}$ in the hydrochar were obtained with the addition of $\mathrm{NaOH}$, formic acid and acetic acid in the HTC of swine manure. Results presented by Reza et al. (2016) from the HTC of glucose in a saline medium corroborated with the previous study showing increased nutrient concentrations $(\mathrm{N}, \mathrm{Fe}$ and $\mathrm{P})$ in hydrochars produced at higher temperatures. In recent work done by our research group, the effect of reaction time, temperature and the presence of phosphoric acid on phosphorus incorporation in hydrochar produced by the HTC of vinasse and bagasse mixture was evaluated (Melo et al., 2016). It was shown that phosphorous was immobilized on the hydrochar possibly through the precipitation of $\mathrm{MgKPO}_{4} \cdot 6 \mathrm{H}_{2} \mathrm{O}, \mathrm{Ca}_{3}\left(\mathrm{PO}_{4}\right)_{2}$ and $\mathrm{Mg}_{3}\left(\mathrm{PO}_{4}\right) \cdot 22 \mathrm{H}_{2} \mathrm{O}$.
HTC from sugarcane bagasse and vinasse has great potential to immobilize nutrients originally present in vinasse and bagasse on the hydrochar. Furthermore, the use of additives, which already contain nutrients, in the reaction medium such as $\mathrm{H}_{3} \mathrm{PO}_{4}, \mathrm{H}_{3} \mathrm{BO}_{3}$, $\mathrm{KOH}, \mathrm{FeCl}_{2}$ e $\left(\mathrm{NH}_{4}\right)_{2} \mathrm{SO}_{4}$, could promote higher immobilization of these nutrients in the hydrochar. In this context, this work proposes to evaluate the effect of the reaction medium on the hydrothermal carbonization of the vinasse and bagasse mixture with the use of acid, base and salt additives at different temperatures, in the immobilization of nutrients $\mathrm{Ca}, \mathrm{Mg}, \mathrm{K}, \mathrm{P}, \mathrm{N}, \mathrm{Cu}, \mathrm{Fe}, \mathrm{B}$, $\mathrm{Mn}$ and $\mathrm{Zn}$ to produce hydrochars with potential for agricultural applications. Other elements such as $\mathrm{Na}, \mathrm{Al}, \mathrm{Cd}, \mathrm{Cr}$ and $\mathrm{Pb}$ were also quantified.

\section{Materials and methods}

\subsection{Materials}

Physical and chemical characteristics from both vinasse and sugarcane bagasse are available in Melo et al. (2016). Sulfuric acid (Qhemis, 98\%), phosphoric acid (Merck, 85\%), boric acid (Synth, 99,5\%), sodium hydroxide (Synth, 97\%), potassium hydroxide (Sigma-Aldrich, 85\%), ferrous chloride tetrahydrate (SigmaAldrich, 99\%) and ammonium sulfate (Synth, 99\%) were employed as additives in solution form in the hydrothermal carbonization reactions.

\subsection{Hydrothermal carbonization process}

The hydrochars were produced in a Teflon ${ }^{\circledR}$ closed reactor coated with stainless steel and heated in a muffle furnace with the temperature already stabilized at 150,190 and $230{ }^{\circ} \mathrm{C} \pm 10^{\circ} \mathrm{C}$ for $13 \mathrm{~h}$. The vinasse and bagasse mixture was used in the proportion of 20:1 (v/w) along with each individual additive solution. In the typical procedure, $3.0 \mathrm{~g}$ of sugarcane bagasse and $60 \mathrm{~mL}$ of pure vinasse or vinasse plus additive $\left(0.1 \mathrm{~mol} \mathrm{~L}^{-1}\right)$ were transferred to the Teflon ${ }^{\circledR}$ cup and stirred for 15 min for homogenization. The final concentration in the reactor for acid additives $\left(\mathrm{H}_{2} \mathrm{SO}_{4}\right.$, $\left.\mathrm{H}_{3} \mathrm{PO}_{4}, \mathrm{H}_{3} \mathrm{BO}_{3}\right)$, bases $(\mathrm{NaOH}, \mathrm{KOH})$ and salts $\left(\mathrm{FeCl}_{2},\left(\mathrm{NH}_{4}\right)_{2} \mathrm{SO}_{4}\right)$ was $0.1 \mathrm{~mol} \mathrm{~L}^{-1}$. In addition, hydrochars from the vinasse and bagasse mixture with no additive were also obtained, for comparison purposes. The experimental variability in the hydrochar production was evaluated conducting at least two reactions for the same conditions of HTC. The hydrochars produced were named as follows: $\mathrm{H}$ for Hydrochar, followed by the molecular formula of the additive or without additive (WA) and the temperature used (HAdditiveTemperature). For example, the hydrochar HWA150 is produced without additives at $150{ }^{\circ} \mathrm{C}$ and $\mathrm{HH}_{2} \mathrm{SO}_{4} 230$ is the hydrochar produced with the addition of $\mathrm{H}_{2} \mathrm{SO}_{4}$ to the reaction medium at $230^{\circ} \mathrm{C}$. At the end of each reaction, the reactor was cooled in an ice bath to stop the reaction. Hydrochars were separated from aqueous phase by vacuum filtration using qualitative filter paper (Nalgon, porosity of $44 \mu \mathrm{m}$ ). The hydrochars were washed with deionized water until a constant $\mathrm{pH}$ was reached and oven dried for $24 \mathrm{~h}$ at $50^{\circ} \mathrm{C}$.

The mass yield for each hydrochar was evaluated considering the dry mass of the hydrochar, and the dry mass of the vinasse and bagasse mixture with no additive or the dry mass of the vinasse and bagasse mixture with its additives.

\subsection{Characterization of hydrochars}

The moisture, organic matter and ash contents were determined using the D2974-14 method (APHA/AWWA/WEF, 2012). 
The elemental composition of $\mathrm{C}, \mathrm{H}, \mathrm{N}$ and $\mathrm{S}$ were determined using an elemental analyzer (Fisons, EA 1108, USA). The oxygen content was obtained by subtraction using the following expression: $\mathrm{O}=100-(\mathrm{C}+\mathrm{H}+\mathrm{N}+\mathrm{S}+$ Ash $)$.

The structural characterization was done by Fourier transform infrared spectroscopy with (FTIR) and X-ray power diffraction (XRD). ATR-FTIR spectra were obtained using a spectrometer (Perkin Elmer, Spectrum Two UATR, USA) in the spectral range 4000$400 \mathrm{~cm}^{-1}$ with 20 scans and a resolution of $4 \mathrm{~cm}^{-1}$. X-ray diffractograms of the solids (powders) were obtained at room temperature using $\mathrm{CuK} \alpha$ radiation $(\lambda=1.5406 \AA$ ) generated at $40 \mathrm{kV}$ and $40 \mathrm{~mA}$ in a X-ray diffractometer (Bruker, D8 Advance powder, USA). The angular range of the measurements (20) was from 5 to $85^{\circ}$, using steps of $0.02^{\circ}$ and an accumulation time of $1 \mathrm{~s}$ per step.

For the elemental analysis (K, Ca, $\mathrm{P}, \mathrm{Mg}, \mathrm{Al}, \mathrm{Zn}, \mathrm{Cu}, \mathrm{Mn}, \mathrm{Fe}, \mathrm{B}, \mathrm{Na}$, $\mathrm{Cr}, \mathrm{Cd}$, and $\mathrm{Pb}$ ) of sugarcane bagasse, vinasse and the resulting hydrochars, these were decomposed first in concentrated nitric acid (Synth, 65\%) and hydrogen peroxide (Vetec, 30\%) under heating, according to the 3050B method (Environmental Protection Agency, 1996). Then, the $\mathrm{Ca}, \mathrm{Mg}, \mathrm{K}, \mathrm{Na}, \mathrm{Al}, \mathrm{Fe}, \mathrm{Cu}, \mathrm{Mn}$ and $\mathrm{Zn}$ elements were quantified in the decomposed samples using a flame atomic absorption spectrophotometer (Varian, AA240FS, USA). B, $\mathrm{Cd}, \mathrm{Cr}$, and $\mathrm{Pb}$ were quantified using a graphite furnace atomic absorption spectrophotometer (Varian, AA280Z, USA). The concentration of phosphorus was determined by the vanadomolybdophosphoric acid colorimetric method (APHA/AWWA/WEF, 2012) using a spectrophotometer in the visible region (Fento, 700Plus, Brazil). The analytical variability was evaluated by carrying out the decomposition and analysis of samples in triplicate.

\section{Results and discussion}

\subsection{Mass yield of hydrochars}

Mass yield is an important parameter in the process of obtaining the hydrochars since it reveals information about the conversion of the original raw material. This parameter is influenced by variables of the HTC process, such as: the nature of the biomasses used, reaction temperature, reaction time, reaction medium $\mathrm{pH}$ and the addition of inorganic salts, amongst others (Hoekman et al., 2013; Lu et al., 2013, 2014).

Fig. 1 shows the mass yield of hydrochars produced in different reaction medium at 150,190 and $230^{\circ} \mathrm{C}$. In general, the mass yield

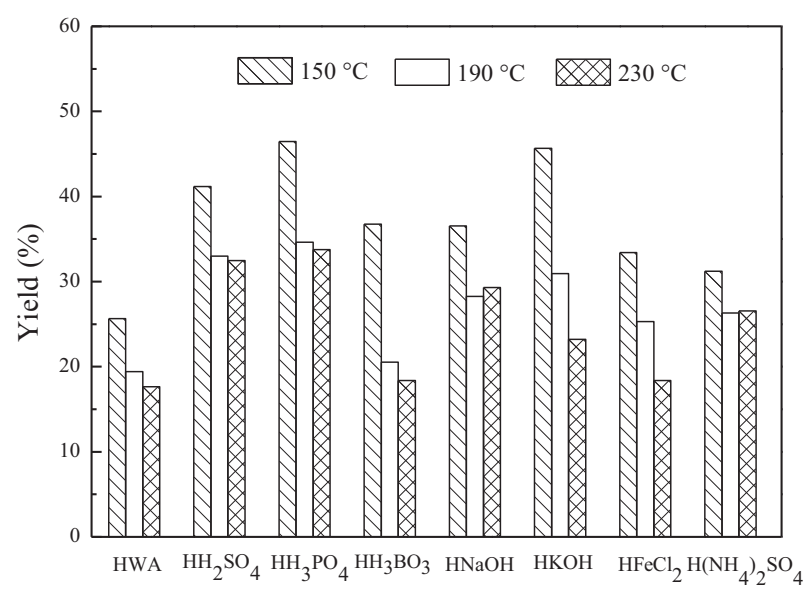

Fig. 1. Mass yield of hydrochars obtained from the hydrothermal carbonization of the vinasse and bagasse mixture with no additives (HWA) and in the presence of acids, bases and salts additives, at 150,190 and $230{ }^{\circ} \mathrm{C}$. Relative standard deviation (RSD) for yield was below $2 \%(n=3)$. ranged from 17.6 to $46.5 \%$, with higher yields at $150{ }^{\circ} \mathrm{C}$ and lower yields at $230^{\circ} \mathrm{C}$. The lower yield at higher temperatures is due to the fact that the conversion of the raw material to carbon is more effective. Sugarcane bagasse is made up of cellulose and hemicellulose, which decompose at temperatures up to $230^{\circ} \mathrm{C}$ (Hu et al., 2010). It is noteworthy that the high content of organic matter $\left(80 \mathrm{~g} \mathrm{~L}^{-1}\right)$ contained in the vinasse would also be degraded with increasing temperature, contributing to the mass yield of the hydrochars.

The addition of acids, bases and salts to the HTC reaction medium for the vinasse and bagasse mixture promoted higher mass yields when compared to the hydrochars produced with no additive. In contrast, Lu et al. (2014) showed that the addition of acids, bases and salts, except for adding $\mathrm{CaCl}_{2}$, decreased the yield of hydrochars produced from cellulose at $250^{\circ} \mathrm{C}$. The addition of $0.5 \mathrm{~N} \mathrm{CaCl}_{2}$ resulted in a greater yield due to the high concentration of $\mathrm{Ca}^{2+}$ ions, making possible the formation of insoluble compounds and therefore increasing the yield.

In this study, the addition of $\mathrm{H}_{2} \mathrm{SO}_{4}$ and $\mathrm{H}_{3} \mathrm{PO}_{4}$ to the reaction medium led to high yields (from 33 to $46 \%$ ) if compared with other additives at the same temperature (Fig. 1). It was expected that, by adding acids to reaction medium, the carbonization of the organic matter present in the raw materials would be more effective, generating lower yields. However, an inverse behavior was observed, suggesting that the addition of these acids could be contributing not only to the conversion of organic matter, but also to the formation of insoluble compounds, through precipitation reactions involving cations and anions present in the vinasse and/or in the sugarcane bagasse and in the additives. In addition, the $\mathrm{pH}$ values for the reactions with acid, base and salt additives were at the same order of magnitude, and did not vary between the reactions (Table 1).

\subsection{Chemical properties}

Table 1 shows the moisture, organic matter and ash content of the hydrochars produced from the HTC of the vinasse and bagasse mixture with no additive and with the addition of acids, bases and salts at 150,190 and $230^{\circ} \mathrm{C}$. In general, the moisture and organic matter content decreased with increasing temperature for all hydrochars. The decrease in moisture is, probably, due to the reduction of the pore volume in the hydrochar and also to the higher degree of carbonization that makes the hydrochar more hydrophobic. On the other hand, the decrease in organic matter is attributed to the higher degree of carbonization at elevated temperatures. This behavior is commonly observed in hydrochars produced using different raw materials (Libra et al., 2011). Moisture and organic matter content varied little among the hydrochars in this study, both when considering the chemical nature of the additives and the temperatures used. These parameters were of the order of $3.5 \%$ for moisture and $86 \%$ for organic matter.

The ash content observed in all the hydrochars varied significantly due to the increase in temperature and the presence of the additives (Table 1). The increase in temperature promoted an increase in the ash content for all carbonizations. This increase was at least $50 \%$ higher for the reactions done at $230{ }^{\circ} \mathrm{C}$ when compared to those conducted at $150{ }^{\circ} \mathrm{C}$, except for the reactions conducted in $\mathrm{FeCl}_{2}$. In addition, considering the presence of the additives in the reaction medium, the ash content was generally higher when compared to the hydrochar produced with the vinasse and bagasse mixture with no additive at $230^{\circ} \mathrm{C}$. This shows that the higher yields observed in the hydrochars produced with the additives could be from the higher ash content seen in these samples. The increase of the ash content corroborates the hypothesis of the precipitation reactions involving the ionic components present in the vinasse and sugarcane bagasse and the ions from 
Table 1

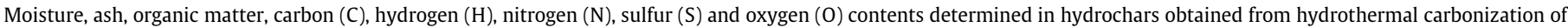

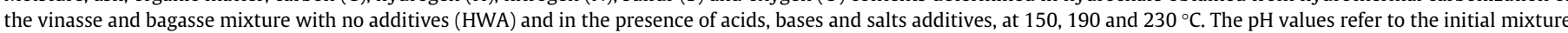
of sugarcane bagasse, vinasse and additives. Relative standard deviation (RSD) for ultimate and proximate analysis was below $5 \%(\mathrm{n}=3$ ).

\begin{tabular}{|c|c|c|c|c|c|c|c|c|c|c|}
\hline Experiments & Temperature $\left({ }^{\circ} \mathrm{C}\right)$ & $\mathrm{pH}$ & Moisture (\%) & Ash (\%) & Organic Matter (\%) & $\mathrm{C}(\%)$ & $\mathrm{H}(\%)$ & $\mathrm{N}(\%)$ & $\mathrm{S}(\%)$ & $\mathrm{O}(\%)$ \\
\hline \multirow[t]{3}{*}{ HWA } & 150 & 4.57 & 5.2 & 5.5 & 89.4 & 55.1 & 6.1 & 3.3 & 1.4 & 28.5 \\
\hline & 190 & 4.57 & 2.8 & 9.4 & 87.8 & 61.4 & 5.7 & 3.7 & 1.8 & 18.1 \\
\hline & 230 & 4.58 & 2.3 & 12.2 & 85.5 & 66.5 & 6.5 & 3.8 & 1.5 & 9.4 \\
\hline \multirow[t]{3}{*}{$\mathrm{HH}_{2} \mathrm{SO}_{4}$} & 150 & 4.34 & 5.1 & 3.8 & 91.1 & 62.8 & 7.6 & 3.8 & 0.3 & 21.8 \\
\hline & 190 & 4.43 & 3.5 & 7.4 & 89.1 & 69.6 & 8.3 & 4.8 & 0.3 & 9.6 \\
\hline & 230 & 3.95 & 3.1 & 11.4 & 85.5 & 71.7 & 7.9 & 4.6 & 0.9 & 3.6 \\
\hline \multirow[t]{3}{*}{$\mathrm{HH}_{3} \mathrm{PO}_{4}$} & 150 & 4.34 & 5.1 & 8.3 & 86.6 & 57.0 & 7.1 & 3.4 & 0.2 & 24.1 \\
\hline & 190 & 4.42 & 3.4 & 12.4 & 84.1 & 65.6 & 7.5 & 4.3 & 0.2 & 10.1 \\
\hline & 230 & 4.35 & 3.3 & 17.2 & 79.5 & 66.6 & 6.8 & 4.1 & 0.2 & 5.2 \\
\hline \multirow[t]{3}{*}{$\mathrm{HH}_{3} \mathrm{BO}_{3}$} & 150 & 4.69 & 5.2 & 6.1 & 88.7 & 58.3 & 7.8 & 3.2 & 0.3 & 24.2 \\
\hline & 190 & 4.68 & 4.1 & 7.9 & 88.0 & 65.8 & 7.1 & 3.7 & 1.2 & 14.4 \\
\hline & 230 & 4.64 & 2.7 & 13.1 & 84.1 & 66.5 & 5.8 & 4.5 & 2.4 & 7.7 \\
\hline \multirow[t]{3}{*}{$\mathrm{HNaOH}$} & 150 & 5.00 & 3.7 & 9.3 & 87.0 & 54.0 & 5.9 & 4.0 & 1.1 & 25.7 \\
\hline & 190 & 5.00 & 3.7 & 9.3 & 87.0 & 64.9 & 6.6 & 4.8 & 1.1 & 13.4 \\
\hline & 230 & 5.05 & 2.1 & 13.0 & 84.9 & 65.7 & 6.2 & 5.1 & 1.7 & 8.3 \\
\hline \multirow[t]{3}{*}{$\mathrm{HKOH}$} & 150 & 4.60 & 3.9 & 4.9 & 91.2 & 56.6 & 6.3 & 3.8 & 0.9 & 27.5 \\
\hline & 190 & 4.63 & 3.0 & 8.9 & 88.1 & 64.1 & 6.3 & 4.9 & 1.5 & 14.4 \\
\hline & 230 & 4.59 & 3.0 & 13.0 & 83.9 & 65.6 & 6.2 & 4.4 & 2.0 & 8.9 \\
\hline \multirow[t]{3}{*}{$\mathrm{HFeCl}_{2}$} & 150 & 4.37 & 7.1 & 11.1 & 81.9 & 54.0 & 6.2 & 3.5 & 1.2 & 24.1 \\
\hline & 190 & 4.35 & 3.2 & 13.0 & 83.8 & 59.6 & 5.9 & 4.0 & 1.9 & 15.7 \\
\hline & 230 & 4.40 & 2.8 & 14.0 & 83.2 & 63.2 & 5.8 & 3.8 & 1.3 & 11.9 \\
\hline \multirow[t]{3}{*}{$\mathrm{H}\left(\mathrm{NH}_{4}\right)_{2} \mathrm{SO}_{4}$} & 150 & 4.60 & 5.4 & 6.9 & 87.7 & 55.3 & 6.0 & 4.2 & 1.2 & 26.5 \\
\hline & 190 & 4.71 & 3.2 & 11.3 & 85.5 & 60.7 & 5.8 & 4.9 & 2.2 & 15.1 \\
\hline & 230 & 4.70 & 2.9 & 16.0 & 81.1 & 63.3 & 5.9 & 5.3 & 3.0 & 6.6 \\
\hline
\end{tabular}

the additives. The addition of $\mathrm{H}_{3} \mathrm{PO}_{4}$ generated hydrochars with the highest ash contents, followed, by those produced with the addition of $\mathrm{FeCl}_{2}$ and $\left(\mathrm{NH}_{4}\right)_{2} \mathrm{SO}_{4}$. The formation of phosphates and sulfates with low solubility as well as the formation of metal oxides/ hydroxides could be responsible for this increase in the ash content. It is worth mentioning that hydrochars have oxygenated chemical functions on their surface (see FTIR) that could act as adsorption sites for metallic cations. In this way, different nutrients could be immobilized/encapsulated/adsorbed in the hydrochars.

The concentrations of the nutrients $\mathrm{Ca}, \mathrm{Mg}, \mathrm{K}, \mathrm{N}, \mathrm{Cu}, \mathrm{Mn}, \mathrm{Zn}, \mathrm{B}, \mathrm{P}$ and $\mathrm{Fe}$ in the hydrochars produced with the vinasse and bagasse mixture with no additive and with the addition of acids, bases and salts at 150,190 and $230{ }^{\circ} \mathrm{C}$ are shown in Fig. 2. The increase in temperature caused an increase in the final concentration of all the nutrients in the hydrochars, with the exception of $\mathrm{Cu}$ and B. This behavior shows that the immobilization of the nutrients in the hydrochar is favored by raising the temperature. Reza et al. (2013) verified, in the HTC of miscanthus, corn stover, switch grass and rice hulls in an aqueous medium, that the increase in temperature from 200 to $260^{\circ} \mathrm{C}$ furthered the release of $\mathrm{Ca}, \mathrm{Mg}$, $\mathrm{K}, \mathrm{S}$ and $\mathrm{P}$ to the aqueous phase, decreasing the concentration in the hydrochar. This observation was explained by the degradation of the hemicellulose that initially contained these inorganic elements in its composition. However, in the raw material with higher cellulose content (miscanthus), the leaching was less effective due to the possible formation of porous carbon that could adsorb inorganic ions reducing the release of these nutrients to the aqueous phase (Reza et al., 2013).

In this study, some factors may be contributing to the immobilization of the nutrients on the hydrochar due to the increase in temperature. The sugarcane bagasse has high cellulose and hemicellulose (61.8\%) and lignin (11\%) content and vinasse also has a high content of organic matter (Table S1). Both materials contributed to the formation of porous carbon particles, characteristic of cellulose carbonization (Guiotoku et al., 2012) and lignin-like chemical compounds. An increase in lignin content to $74 \%$ was observed in the hydrochars (Table S1) that could adsorb the macro and micronutrients present in the vinasse itself (Table S2) and in the additives used. The concentrations of the macronutrients $\mathrm{N}$, $\mathrm{Ca}, \mathrm{Mg}$ and $\mathrm{K}$ ranged $31-52 \mathrm{~g} \mathrm{~kg}^{-1}, 1$ to $24 \mathrm{~g} \mathrm{~kg}^{-1}, 0.2$ to $15 \mathrm{~g} \mathrm{~kg}^{-1}$ and 0.4 to $4 \mathrm{~g} \mathrm{~kg}^{-1}$ in the hydrochars, respectively (Fig. 2a). In general, for the hydrochars produced only with the vinasse and bagasse mixture, the macronutrient concentrations were lower than those of the hydrochars produced with the use of the additives. These results indicate that the additives promote the immobilization of the macronutrients on the hydrochar, and the chemical nature of each additive influences the respective amounts of each nutrient.

Of the macronutrients, the potassium concentrations were lower in the hydrochars. However, higher concentrations of this nutrient were observed in hydrochars produced from reaction medium containing $\mathrm{H}_{2} \mathrm{SO}_{4}, \mathrm{H}_{3} \mathrm{PO}_{4}$ and $\left(\mathrm{NH}_{4}\right)_{2} \mathrm{SO}_{4}$. Because potassium is a very soluble alkaline earth metal with a high ionization constant (Skoog et al., 2004), it is unlikely to be incorporated in the solid matrix, remaining in the aqueous phase. However, additives can promote the immobilization of the element as inorganic precipitates of low crystallinity, such as struvite- $\mathrm{K}\left(\mathrm{KMgPO}_{4} \cdot 6 \mathrm{H}_{2} \mathrm{O}\right.$ or $\mathrm{NH}_{4} \mathrm{MgPO}_{4} \cdot 6 \mathrm{H}_{2} \mathrm{O}$ ). The molar ratios between the nutrients $\mathrm{K}, \mathrm{Mg}$ and $\mathrm{P}$ of the hydrochars produced from reaction medium containing $\mathrm{H}_{2} \mathrm{SO}_{4}, \mathrm{H}_{3} \mathrm{PO}_{4}$ and $\left(\mathrm{NH}_{4}\right)_{2} \mathrm{SO}_{4}$ were $1: 1: 1$, suggesting the formation of the precipitate struvite-K. The molar ratios of the nutrients $\mathrm{N}, \mathrm{Mg}$ and $\mathrm{P}$ in the hydrochars produced with the addition of the same additives mentioned above were $2: 1: 1$

The highest $\mathrm{Mg}$ concentrations were obtained with the addition of $\mathrm{H}_{3} \mathrm{PO}_{4}, \mathrm{NaOH}$ and $\mathrm{KOH}$. $\mathrm{Mg}$ is an element that precipitates at basic $\mathrm{pH}$, with a higher concentration of $\mathrm{OH}^{-}$in the reaction medium (Semerjian and Ayoub, 2003). Thus, higher concentrations of $\mathrm{Mg}$ observed in hydrochars produced from the reaction medium containing the bases would be due to the precipitation of $\mathrm{Mg}$ $(\mathrm{OH})_{2}$. On the other hand, $\mathrm{Mg}$ observed in the hydrochars produced by adding $\mathrm{H}_{3} \mathrm{PO}_{4}$ is possibly due the formation of struvite- $\mathrm{K}$ or magnesium phosphates, as also observed by Melo et al. (2016). 

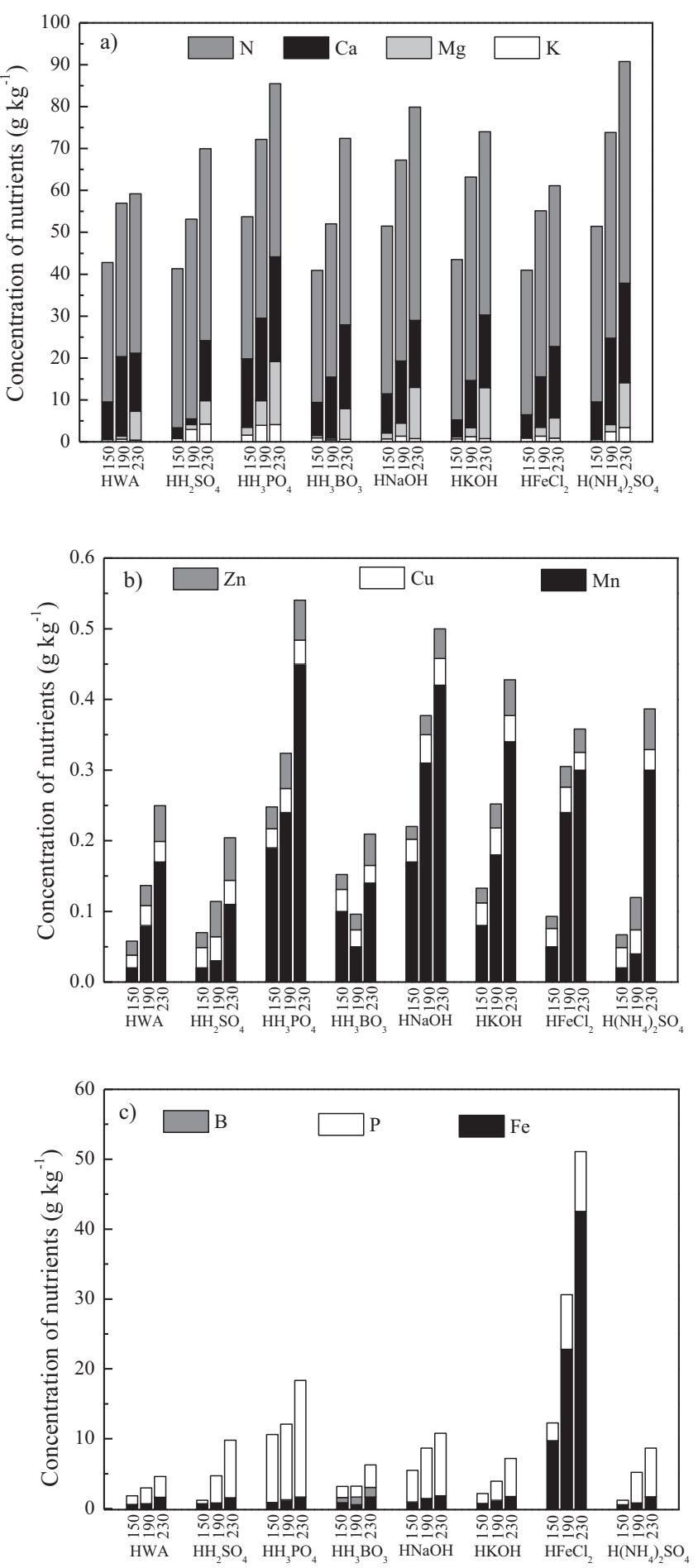

Fig. 2. Nutrient concentration ( $\mathrm{g} \mathrm{kg}^{-1}$ ) of a) nitrogen (N), calcium (Ca), magnesium $(\mathrm{Mg})$, potassium $(\mathrm{K})$; b) zinc $(\mathrm{Zn})$, copper $(\mathrm{Cu})$, manganese $(\mathrm{Mn})$; and $\mathrm{c}$ ) phosphorus $(\mathrm{P})$, boron (B) and iron (Fe) in the hydrochars obtained from the hydrothermal carbonization of the vinasse and bagasse mixture in the absence and presence of the addition of acids, bases and salts, at 150,190 and $230{ }^{\circ} \mathrm{C}$. Relative standard deviation (RSD) for each metal concentration was below $5 \%(n=3)$.

For $\mathrm{Ca}$, the highest concentrations were obtained in hydrochars produced with the addition of $\mathrm{H}_{3} \mathrm{PO}_{4}$ and $(\mathrm{NH} 4)_{2} \mathrm{SO}_{4}$ to the reaction medium. The presence of these additives promoted the formation of insoluble phosphates and sulfates (see section 3.4).

The highest concentrations of $\mathrm{N}$ were seen in hydrochars produced with a reaction medium containing $\mathrm{H}_{2} \mathrm{SO}_{4}$ and $\left(\mathrm{NH}_{4}\right)_{2} \mathrm{SO}_{4}$.
The concentrations of $\mathrm{N}$ determined in the hydrochars produced with the vinasse and bagasse mixture are considered high when compared with other studies in the literature that used different biomasses, whether lignocellulosic or not, and for HTC conducted above $200^{\circ} \mathrm{C}$ (Danso-Boateng et al., 2015; Hoekman et al., 2013; Wiedner et al., 2013). The contribution of vinasse in the HTC process in the immobilization of $\mathrm{N}$ is important, since the concentration of $\mathrm{N}$ in sugarcane bagasse is low. There are studies showing that the concentration of $\mathrm{N}$ increases with the increase in temperature, for example, in HTC of wheat straw, poplar wood and olive residues (Wiedner et al., 2013), while another described an inverse behavior, showing the degradation of N in the HTC of human faecal waste (Danso-Boateng et al., 2013). This difference is mainly due to the raw materials used and the chemical forms that the $\mathrm{N}$ takes in each matrix. The immobilization of the macronutrients $\mathrm{N}, \mathrm{Ca}, \mathrm{Mg}$ and $\mathrm{K}$ in hydrochar produced with the vinasse and bagasse mixture was favored, especially with the addition of $\mathrm{H}_{2} \mathrm{SO}_{4}, \mathrm{H}_{3} \mathrm{PO}_{4}$ and $\left(\mathrm{NH}_{4}\right)_{2} \mathrm{SO}_{4}$ to the reaction medium.

The concentrations of the $\mathrm{Zn}, \mathrm{Cu}$ and $\mathrm{Mn}$ micronutrients in the hydrochars varied from 0.02 to $0.06 \mathrm{~g} \mathrm{~kg}^{-1}$, from 0.02 to $0.04 \mathrm{~g} \mathrm{~kg}^{-1}$ and from 0.02 to $0.45 \mathrm{~g} \mathrm{~kg}^{-1}$, respectively (Fig. 2b). The addition of acids, bases and salts only facilitated the immobilization of $\mathrm{Zn}$ and $\mathrm{Mn}$, and the concentrations of these elements were highest when using $\mathrm{H}_{2} \mathrm{SO}_{4}$ and $\mathrm{H}_{3} \mathrm{PO}_{4}$ in the reaction medium, respectively. Concentrations of $\mathrm{Cu}$ remained at the same order of magnitude in hydrochars produced without and with additives, and did not vary with temperature.

Fig. 2c shows the concentrations of the nutrients $\mathrm{P}, \mathrm{B}$ and $\mathrm{Fe}$ in hydrochars produced at 150,190 and $230^{\circ} \mathrm{C}$. These nutrients are shown separately from the others because $\mathrm{H}_{3} \mathrm{PO}_{4}, \mathrm{H}_{3} \mathrm{BO}_{3}$ and $\mathrm{FeCl}_{2}$ were added in order to provide nutrients $\mathrm{P}, \mathrm{B}$ and Fe to the hydrochars. In general, the concentrations of the nutrients $P$ and Fe were higher in the hydrochars produced with the addition of acids, bases and salts when compared to those hydrochars produced only with the vinasse and bagasse. The presence of $\mathrm{B}$, an essential micronutrient for growth of various crops, not present in the raw materials used, was only seen in the $\mathrm{HTC}$ with the addition of $\mathrm{H}_{3} \mathrm{BO}_{3}$. The concentrations of $\mathrm{B}$ increased with increasing temperature $(0.77$ to $1.37 \mathrm{~g} \mathrm{~kg}^{-1}$ ). Tekin et al. (2013) evaluated the hydrothermal carbonization of wood using boric acid. However, these authors only analyzed the mass yield and the variation of composition of carbon and oxygen in the hydrochars and the immobilization of boron was not discussed (Tekin et al., 2013).

The Fe concentrations ranged from 0.55 to $1.81 \mathrm{~g} \mathrm{~kg}^{-1}$ in hydrochars produced with and without the presence of additives (except for $\mathrm{FeCl}_{2}$. In hydrochars produced with the addition of $\mathrm{FeCl}_{2}$, there was an increase in the concentration of the nutrient, ranging from 9.7 to $42.5 \mathrm{~g} \mathrm{~kg}^{-1}$. The HTC process has been used for the preparation of hydrothermal carbons containing iron oxides for various uses, the iron being encapsulated as nano-oxides in carbonaceous materials or adsorbed on its surface (Yu et al., 2010; Zhao et al., 2013). The immobilization of iron in this study probably occurs through the two mentioned mechanisms, being the more likely the adsorption of iron ions, due to the low final $\mathrm{pH}$ observed in the reactions (data not shown).

The $P$ concentrations ranged from 0.62 to $8.9 \mathrm{~g} \mathrm{~kg}^{-1}$ for all hydrochars produced, with the exception of hydrochars produced with the addition of $\mathrm{H}_{3} \mathrm{PO}_{4}$, where the concentrations were 9.7 to $16.68 \mathrm{~g} \mathrm{~kg}^{-1}$. Thus, the addition of $\mathrm{H}_{3} \mathrm{PO}_{4}$ increased the immobilization of this nutrient in the resulting hydrochar by $50 \%$. Phosphorus immobilization has also been observed in the HTC of animal manure and attributed to the presence of metal cations such as aluminum, calcium, magnesium and iron, which led to the formation of insoluble phosphates such as $\mathrm{Ca}_{3}\left(\mathrm{PO}_{4}\right)_{2}$ and $\mathrm{Mg}_{3}(-$ $\left.\mathrm{PO}_{4}\right)_{2}$ in the hydrochar (Heilmann et al., 2014). Reza et al. (2016) reported the immobilization of phosphorus in the hydrochar when 
glucose was hydrothermally carbonized in the presence of $\mathrm{NH}_{4} \mathrm{H}_{2}$ $\mathrm{PO}_{4}$, and suggested that phosphorus is chemo-adsorbed on the surface of the hydrochar. In this work, the phosphorus was probably immobilized in the hydrochar due to the formation of precipitates.

$\mathrm{Al}$ and $\mathrm{Na}$ concentrations were also determined in the hydrochars since these elements are present in the vinasse composition. However, they are not desirable in materials to be used as a fertilizer (Fig. S1). The Al concentration in all hydrochars ranged from 1.7 to $5.4 \mathrm{~g} \mathrm{~kg}^{-1}$ and there was no increase in concentration either with increasing temperature or with the addition of acids, bases and salts. The concentrations of $\mathrm{Na}$ in the hydrochars varied from 0.25 to $1.36 \mathrm{~g} \mathrm{~kg}^{-1}$ with the highest concentrations being seen with increasing temperature and with the addition of acids, bases and salts. It is important to know about other metals with no nutrient value, such as $\mathrm{Cr}, \mathrm{Cd}$, and $\mathrm{Pb}$, due the toxic effects that they can cause to the environment. $\mathrm{Cr}$ and $\mathrm{Pb}$ ranged from 36.1 to 10.9 and 16.4 to $3.2 \mathrm{mg} \mathrm{kg}^{-1}$, respectively in all hydrochars (Fig. S2). $\mathrm{Cr}$ and $\mathrm{Pb}$ concentrations were below 90 and $150 \mathrm{mg} \mathrm{kg}^{-1}$ respectively, values recommended for the European Biochar Certificate and by the IBI Biochar Standards (EBC, 2015; IBI, 2015). Cd concentrations were below $0.014 \mathrm{mg} \mathrm{kg}^{-1}$ in both vinasse and sugarcane bagasse (Table S2).

From the determinations of $\mathrm{N}, \mathrm{Ca}, \mathrm{Mg}, \mathrm{K}, \mathrm{Cu}, \mathrm{Zn}, \mathrm{Mn}, \mathrm{P}, \mathrm{Fe}$ and $\mathrm{B}$ concentrations in the hydrochars, an analysis of the immobilization percentages of these nutrients was carried out, taking into account the initial concentration of each element in the raw materials and/or additives used in the HTC reactions. Figs. S3-S5 show the percentages of immobilization of the macronutrients $\mathrm{K}, \mathrm{Ca}$, $\mathrm{Mg}$ and $\mathrm{N}$, of the micronutrients $\mathrm{Cu}, \mathrm{Zn}$ and $\mathrm{Mn}$ and of the elements $\mathrm{P}, \mathrm{Fe}$ and $\mathrm{B}$, respectively. In fact, only $1 \%$ of the $\mathrm{K}$ was immobilized on the hydrochars, regardless of the additives and the temperatures used, the rest remaining in the aqueous phase or being leached during the washing stage. The Ca immobilization percentages ranged from 11 to $59 \%$, being immobilized in all hydrochars, especially those produced with the addition of $\mathrm{H}_{2} \mathrm{SO}_{4}, \mathrm{H}_{3} \mathrm{PO}_{4}$ and $\left(\mathrm{NH}_{4}\right)_{2} \mathrm{SO}_{4}$. The higher Mg immobilization percentages (20-38\%) and $\mathrm{N}(42-63 \%)$ were observed in hydrochars produced with the addition of $\mathrm{H}_{3} \mathrm{PO}_{4}$ and $\left(\mathrm{NH}_{4}\right)_{2} \mathrm{SO}_{4}$. Mg immobilization is also seen when $\mathrm{NaOH}$ and $\mathrm{KOH}$ are added. Immobilization of $\mathrm{P}$ ranged from $25 \%$ to $100 \%$. All phosphorus from the vinasse and bagasse mixture was immobilized at $230{ }^{\circ} \mathrm{C}$ when $\mathrm{H}_{2} \mathrm{SO}_{4}, \mathrm{H}_{3} \mathrm{PO}_{4}$ and $\left(\mathrm{NH}_{4}\right)_{2} \mathrm{SO}_{4}$ were added to the reaction medium. In addition, $60 \%$ of $\mathrm{P}$ from the addition of $\mathrm{H}_{3} \mathrm{PO}_{4}$ was also immobilized on the hydrochar. The Fe immobilization percentages ranged from $70-80 \%$ in hydrochars produced with the addition of the acids, $\mathrm{NaOH}$ and $\left(\mathrm{NH}_{4}\right)_{2} \mathrm{SO}_{4}$. Around $50 \%$ of the iron added from $\mathrm{FeCl}_{2}$ was immobilized on the hydrochar. The micronutrient $\mathrm{B}$ was immobilized only when $\mathrm{H}_{3} \mathrm{BO}_{3}$ was added to the reaction medium, with relatively low immobilization (approximately 6\%). $\mathrm{Mn}\left(100 \%\right.$ with $\mathrm{H}_{3} \mathrm{PO}_{4}$ and $\left.\mathrm{NaOH}\right), \mathrm{Cu}(100 \%$ with acids and bases) and $\mathrm{Zn}$ (70\% with acid) were also immobilized on the hydrochar. Only $\mathrm{K}$ and $\mathrm{B}$ had low percentages of immobilization in hydrochars, remaining in the aqueous phase.

The evaluation of the chemical composition of $\mathrm{C}, \mathrm{H}$ and $\mathrm{O}$ (Table 1 ) in the hydrochars provides information about the degree of carbonization that the original raw material underwent. It also allows an assessment of the influence of temperature and the different additives on the carbonization. The $C$ content in the vinasse (dried) and bagasse were 35.2 and $37.2 \%$, respectively (Table S3). In all hydrochars, the $C$ content ranged from 53.9 to $71.7 \%$. The oxygen contents were from 5.1 to $28.5 \%$, values which are lower than the levels obtained in the vinasse (39.3\%) and bagasse (50.8\%). The HTC of the vinasse and bagasse mixture produced hydrochars with higher levels of $\mathrm{C}$ and lower $\mathrm{O}$ content, than observed in other studies of HTC of different raw materials (Hoekman et al., 2013; Kang et al., 2012; Parshetti et al., 2013).
The temperature directly influenced the elemental composition of hydrochars with consecutive increases in the temperature from 150 to $190{ }^{\circ} \mathrm{C}$ and then to $230^{\circ} \mathrm{C}$. The addition of acids, bases and salts also influenced the $C$ content (Table 1 ). The $C$ content and the $\mathrm{O}$ content of the hydrochars produced only from the vinasse and bagasse mixture were lower than the levels observed in hydrochars produced with the addition of acids and bases. Moreover, these levels were higher than those observed in hydrochars produced with the addition of salts. This behavior shows that the addition of acids and bases promoted higher conversion of organic matter, and that the addition of salts acted negatively on carbonization, acting mainly in the inorganic fraction of the reaction product. The highest $\mathrm{C}$ values were observed in hydrochars produced with the addition of $\mathrm{H}_{2} \mathrm{SO}_{4}$ and $\mathrm{H}_{3} \mathrm{PO}_{4}$, which is explained by the fact that acids promote the breaking of $\mathrm{C}-\mathrm{O}$ bonds of hemicellulose and cellulose (Lu et al., 2014; Lynam et al., 2011) (see section 3.3). The addition of these acids promoted higher carbonization of the raw materials, which also leads to lower mass yields. However, as previously discussed, the mass yields in hydrochars produced with $\mathrm{H}_{2} \mathrm{SO}_{4}$ and $\mathrm{H}_{3} \mathrm{PO}_{4}$ were higher than others and this is due to the precipitation of insoluble solids. Thus, the addition of these acids acts strongly both in the conversion of organic matter, increasing the degree of carbonization of the hydrochar, and also in the precipitation of nutrients, increasing the immobilization of $\mathrm{K}, \mathrm{Ca}, \mathrm{Mg}, \mathrm{N}$ and $\mathrm{P}$.

In Fig. 3, the atomic ratios $\mathrm{H} / \mathrm{C}$ and $\mathrm{O} / \mathrm{C}$ of the raw materials (vinasse and bagasse) and of the hydrochars produced are arranged in the form of a van Krevelen diagram. For comparison purposes, equivalent regions for other compositions (biomass, peat, lignite, coal and anthracite) were added (Van Krevelen, 1984). The smaller the $\mathrm{H} / \mathrm{C}$ and $\mathrm{O} / \mathrm{C}$ ratios, the higher the degree of carbonization of the materials obtained (Libra et al., 2011; van der Stelt et al., 2011). The diagram clearly shows that all the hydrochars produced at a given temperature can be arranged into a group, and the lowest $\mathrm{H} / \mathrm{C}$ and $\mathrm{O} / \mathrm{C}$ ratios were obtained for hydrochars produced at $230^{\circ} \mathrm{C}$. Deoxygenation, demethylation and dehydration processes control the HTC of the vinasse and bagasse mixture. The difference between the $\mathrm{H} / \mathrm{C}$ and $\mathrm{O} / \mathrm{C}$ ratios in the hydrochars produced at $150{ }^{\circ} \mathrm{C}$ is quite substantial when compared to those of the other hydrochars produced at 190 and $230^{\circ} \mathrm{C}$. In the hydrochars produced at 190 and $230^{\circ} \mathrm{C}$, the $\mathrm{H} / \mathrm{C}$ ratios remained within the interval of 1.0 to 1.5 , while the $\mathrm{O} / \mathrm{C}$ ratios decreased with increasing temperature. These results show that from $190^{\circ} \mathrm{C}$, only deoxygenation occurs in the formation of the hydrochars, and demethylation reactions are virtually unseen. The addition of bases and salts caused little change to the $\mathrm{H} / \mathrm{C}$ and $\mathrm{O} / \mathrm{C}$ ratios of the hydrochars when compared to the hydrochars produced only with the vinasse and bagasse mixture, these ratios remaining in the same order of magnitude. The largest differences were observed in the hydrochars produced with the addition of acids, where the $\mathrm{H} / \mathrm{C}$ ratio was higher and the $\mathrm{O} / \mathrm{C}$ ratio in these samples was lower than in the other hydrochars.

\subsection{FTIR spectra of hydrochars}

All the FTIR spectra of the hydrochars produced at 150, 190 and $230{ }^{\circ} \mathrm{C}$ produced without and with the presence of the additives, and of the vinasse and sugarcane bagasse mixture, can be seen in Figs. S6-S9.

In general, most of the spectra show bands in the following regions: a broad band in the region of $3500-3300 \mathrm{~cm}^{-1}$, referring to $\mathrm{O}-\mathrm{H}$ and $\mathrm{N}-\mathrm{H}$ stretching modes, three bands in the region of $3000-2800 \mathrm{~cm}^{-1}$ related to the symmetric and asymmetric stretching of $\mathrm{C}-\mathrm{H}$ bonds in aliphatic structures, a discrete band in the region of $1700 \mathrm{~cm}^{-1}$ attributed to $C=0$ stretching in carboxylic acids, a band between 1610 and $1590 \mathrm{~cm}^{-1}$ assigned to 


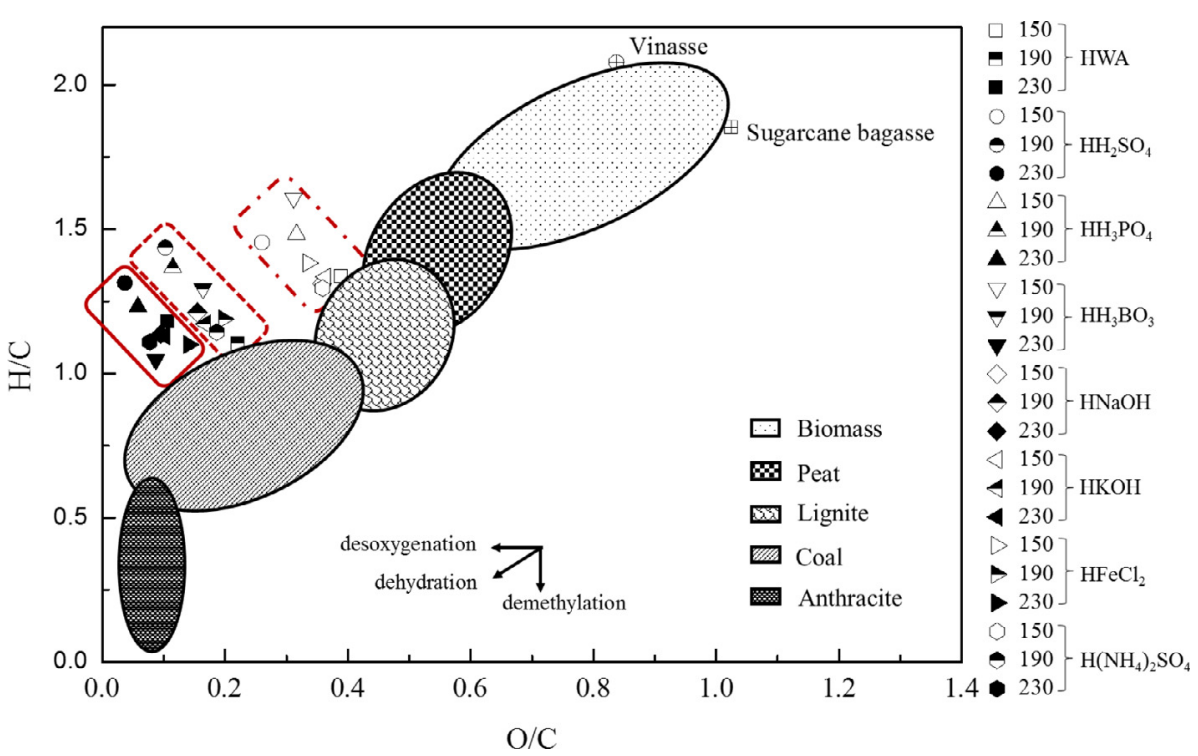

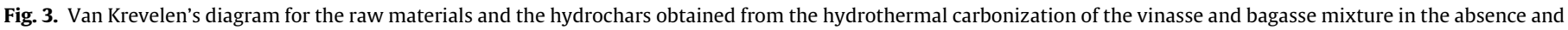
presence of added acids, bases and salts, at 150,190 and $230^{\circ} \mathrm{C}$. Shaded areas for biomass, peat, lignite, coal and anthracite are shown for comparison purposes.

$\mathrm{C}=\mathrm{C}$ vibrations in aromatic rings, two bands in the region of 1530 and $1470 \mathrm{~cm}^{-1}$ assigned to the $\mathrm{N}=\mathrm{O}, \mathrm{N}-\mathrm{H}$ bonds (secondary amide) and $\mathrm{C}-\mathrm{H}$ deformation, and overlapping bands in the region of $1250-1000 \mathrm{~cm}^{-1}$ whose main contribution is related to $\mathrm{C}-\mathrm{O}-\mathrm{C}$ vibration in glycosidic rings.

The HTC of the vinasse and bagasse mixture showed a decrease in the intensity of the broad band in the region of $3300-3500 \mathrm{~cm}^{-1}$ related to the vibrations of hydroxyl groups, indicating the elimination of $\mathrm{H}$ and $\mathrm{O}$, possibly through dehydration reactions, corroborating the information shown in the van Krevelen diagram. The bands between 3000 and $2800 \mathrm{~cm}^{-1}$ attributed to the stretching of the $\mathrm{C}-\mathrm{H}$ bond, were more intense in the hydrochars than those in the raw materials and have profiles related to the $-\mathrm{CH}_{2}$ and $-\mathrm{CH}_{3}$ groups in aliphatic structures. The band in the $1700 \mathrm{~cm}^{-1}$ region ascribed to $\mathrm{C}=\mathrm{O}$ vibrations of carboxylic acids becomes more evident with HTC processing. An analysis of the region of $1250-1000 \mathrm{~cm}^{-1}$ showed that there are changes in the profiles of the bands for the hydrochars when compared to the original raw material. However, it is difficult to make an accurate identification of these bands, since they have very complex profiles (with overlapping bands).

The variation in temperature brought about changes mainly in the bands at: $3500-3300 \mathrm{~cm}^{-1}(\mathrm{OH}), \quad 1700 \mathrm{~cm}^{-1} \quad(\mathrm{C}=\mathrm{O})$, $1600 \mathrm{~cm}^{-1}(\mathrm{C}=\mathrm{C}), 1530$ and $1470 \mathrm{~cm}^{-1}(\mathrm{C}=\mathrm{O}, \mathrm{N}-\mathrm{H}$ and $\mathrm{C}-\mathrm{H})$. On increasing the temperature from 150 to $230^{\circ} \mathrm{C}$, there was a reduction in the intensity, mainly for the band attributed to $\mathrm{O}-\mathrm{H}$ stretching, increased intensity of the band related to $\mathrm{C}=\mathrm{O}$ bonds, disappearance of the band due to $\mathrm{N}=\mathrm{O}$ and changes to the bands related to $\mathrm{C}=\mathrm{C}$ and $\mathrm{N}-\mathrm{H}$ bonds, these latter bands remaining less intense but wider (Figs. S6-S9). These results suggest that the rise in temperature causes further dehydration of the raw materials, the formation of carboxylic acids and the presence of aromatic domains. The presence of carboxylic acids in the structure of the hydrochars gives them the capacity to adsorb the metallic cations, such as the nutrients, $\mathrm{Fe}, \mathrm{Mn}, \mathrm{Ca}$ and $\mathrm{Mg}$, amongst others. This property also explains the immobilization of nutrients in the hydrochars in addition to the precipitation mechanism of insoluble compounds.

The main differences in the spectra profile of the hydrochars produced with the addition of acids, bases and salts were observed below $1250 \mathrm{~cm}^{-1}$ in the FTIR spectra. It is difficult to accurately determine the bands in the $1250-1000 \mathrm{~cm}^{-1}$ region due to the overlapping of different vibrational modes, such as those from $\mathrm{C}-\mathrm{O}-\mathrm{C}, \mathrm{P}-\mathrm{O}, \mathrm{S}-\mathrm{O}$ and $\mathrm{Si}-\mathrm{O}$. Bands in the region below $1000 \mathrm{~cm}^{-1}$ are hardly seen in the FTIR spectrum of the original raw material. Moreover, in the FTIR spectra of hydrochars produced without additives and with $\mathrm{H}_{2} \mathrm{SO}_{4}$ and $\left(\mathrm{NH}_{4}\right)_{2} \mathrm{SO}_{4}$ at $230{ }^{\circ} \mathrm{C}$ (Figs. S7 and S9), the bands related to the $\mathrm{S}-\mathrm{O}$ of sulfates at 670 and $590 \mathrm{~cm}^{-1}$ are easily identified (Makreski et al., 2005). In the hydrochars produced with the addition of $\mathrm{H}_{3} \mathrm{PO}_{4}$, bands between 600 and $550 \mathrm{~cm}^{-1}$ were observed, related to calcium phosphate hydroxide (Linstrom and Mallard, 2014).

\subsection{XRD of hydrochars}

All diffractograms of the hydrochars are shown in Figs. S10-S13. The XRD patterns showed broad and low intensity peaks, between 10 and $30^{\circ}(2 \theta)$, overlapping the narrow and intense peaks. These diffraction profiles showed that the reaction products are composed of carbonaceous materials with low structural order like amorphous carbon (responsible for broad peaks of low intensity) and also crystalline material (responsible for the narrow peaks of high intensity). In the diffractograms of hydrochars produced at a $150{ }^{\circ} \mathrm{C}$, two broad peaks were superimposed on the amorphous halo (Figs. S10-S13). These peaks were due to the remaining cellulose of the sugarcane bagasse showing partial carbonization at milder temperatures (Sevilla and Fuertes, 2009). The increase in temperature led to the disappearance of the characteristic cellulose peaks in the hydrochars.

The higher mass yields and ash content obtained in the hydrochars produced with the addition of acids, bases and salts were attributed in part to the presence of insoluble inorganic precipitates, particularly with the addition of $\mathrm{H}_{2} \mathrm{SO}_{4}, \mathrm{H}_{3} \mathrm{PO}_{4}$ and $\left(\mathrm{NH}_{4}\right)_{2} \mathrm{SO}_{4}$ to the reaction medium. Two major crystalline phases were found in all the hydrochars: $\mathrm{CaSO}_{4}$ (ICSD 016382 or ICSD 00260328) and $\mathrm{SiO}_{2}$ (ICSD 034923 or ICSD 089279). The calcium sulfate has its origin in the precipitation reaction of calcium and sulfate in the vinasse and also due to the sulfate present as an anion in the $\mathrm{H}_{2} \mathrm{SO}_{4}$ and $\left(\mathrm{NH}_{4}\right)_{2} \mathrm{SO}_{4}$ additives. This result justifies the higher calcium concentrations determined in these hydrochars (Fig. 2a). The silicon oxide originates from the processing of sugarcane and is also found in the bagasse itself. In the diffractograms of hydrochars produced with the addition of $\mathrm{H}_{2} \mathrm{SO}_{4}$ and $\left(\mathrm{NH}_{4}\right)_{2} \mathrm{SO}_{4}$, the struvite- $\mathrm{K}$ crystalline phase $\left(\mathrm{KMgPO}_{4} \cdot 6 \mathrm{H}_{2} \mathrm{O}\right)$ was not seen (Figs. $\mathrm{S} 11$ and $\mathrm{S} 13$ ). 
This is possibly due to the low concentration of $\mathrm{K}$ and $\mathrm{Mg}$ in the hydrochar (less than $5 \%$ by weight) or the struvite- $K$ is present as an amorphous phase and not detectable in XRD analysis. For the hydrochar produced at $230{ }^{\circ} \mathrm{C}$ in the presence of $\mathrm{H}_{3} \mathrm{PO}_{4}$, calcium phosphate $\left(\mathrm{Ca}_{2} \mathrm{P}_{6} \mathrm{O}_{17}\right.$ - ICDD 150203) was formed (Fig. S11), explaining the higher $\mathrm{P}$ concentrations found.

\section{Conclusions}

The immobilization of macro and micronutrients in hydrochars produced from the hydrothermal carbonization of the vinasse and sugarcane bagasse mixture depends on the temperature and also on the additive used in the reaction medium. The addition of $\mathrm{H}_{2} \mathrm{SO}_{4}, \mathrm{H}_{3} \mathrm{PO}_{4}$ and $\left(\mathrm{NH}_{4}\right)_{2} \mathrm{SO}_{4}$ favored higher immobilization of nutrients such as $\mathrm{P}, \mathrm{N}, \mathrm{Ca}, \mathrm{Mg}$ and $\mathrm{K}$. The addition of $\mathrm{H}_{2} \mathrm{SO}_{4}$ and $\mathrm{H}_{3} \mathrm{PO}_{4}$ also produced a higher degree of carbonization increasing the $\mathrm{C}$ content. The immobilization of nutrients occurs both by adsorption on the surface of the hydrochar and also the precipitation of insoluble compounds.

\section{Acknowledgments}

The authors are grateful to the Laboratório de Sucroquímica e Química Analítica - UNESP/IBILCE for providing the infrared spectrometer. O. P. F and M. C. B. also acknowledge support from CNPq (Grants 478743/2013-0 and 445487/2014-3) and FUNCAP (PRONEX PR2-0101-00006.01.00/15). We also appreciate the financial support and scholarship from FAPESP (Grants 2013/21776-7 and 2014/22400-3) and scholarship from CAPES. M. C. B. is a recipient of a productivity fellowship by CNPq (307925/2012-9).

\section{Appendix A. Supplementary data}

Supplementary data associated with this article can be found, in the online version, at http://dx.doi.org/10.1016/j.biortech.2017.04. 004.

\section{References}

APHA/AWWA/WEF, 2012. Standard Methods for the Examination of Water and Wastewater, Standard Methods.

Brito, F., Rolim, M., Pedrosa, E., 2005. Teores de potássio e sódio no lixiviado e em solos após a aplicação de vinhaça solos após a aplicação de vinhaça. Rev. Bras. Eng. Agrícola e Ambient. 9, 52-56.

Brito, F.L., Rolim, M.M., Pedrosa, E.M.R., 2007. Concentração de cátions presentes no lixiviado de solos tratados com vinhaça. Eng. Agrícola 27, 773-781. http://dx. doi.org/10.1590/S0100-69162007000400021.

Christofoletti, C.A., Escher, J.P., Correia, J.E., Marinho, J.F.U., Fontanetti, C.S., 2013. Sugarcane vinasse: environmental implications of its use. Waste Manage. 33, $2752-2761$.

Dai, L., Tan, F., Wu, B., He, M., Wang, W., Tang, X., Hu, Q., Zhang, M., 2015. Immobilization of phosphorus in cow manure during hydrothermal carbonization. J. Environ. Manage. 157, 49-53.

Danso-Boateng, E., Holdich, R.G., Shama, G., Wheatley, A.D., Sohail, M., Martin, S.J., 2013. Kinetics of faecal biomass hydrothermal carbonisation for hydrochar production. Appl. Energy 111, 351-357. http://dx.doi.org/10.1016/j. apenergy.2013.04.090.

Danso-Boateng, E., Holdich, R.G., Martin, S.J., Shama, G., Wheatley, A.D., 2015. Process energetics for the hydrothermal carbonisation of human faecal wastes. Energy Convers. Manag. 105, 1115-1124. http://dx.doi.org/10.1016/j. enconman.2015.08.064.

EBC, 2015. European Biochar Certificate - Guidelines for a Sustainable Production of Biochar'. Eur. Biochar Found. (EBC), Arbaz, Switzerland, pp. 1-22. http://dx.doi. org/10.13140/RG.2.1.4658.7043. Version 6.1 19th June.

Ekpo, U., Ross, A.B., Camargo-Valero, M.A., Fletcher, L.A., 2016. Influence of pH on hydrothermal treatment of swine manure: impact on extraction of nitrogen and phosphorus in process water. Bioresour. Technol. 214, 637-644. http://dx.doi. org/10.1016/j.biortech.2016.05.012.

Environmental Protection Agency, 1996. Acid digestion of sediments, sludges, and soils. In: Test Methods for Evaluating Solid Waste, Physical/Chemical Methods (SW-846), pp. 1-12. http://dx.doi.org/10.1117/12.528651.

FAO, 2015. World Fertilizer Trends and Outlook to 2018. Food and Agriculture Organization of United Nations.
FAO, 2016. Food and agriculture organization of the United Nations statistics division [WWW Document]. Trade/Crops Livest. Prod. URL: <http://faostat3.fao. org/browse/T/TP/E>.

Ferreira-Leitão, V., Gottschalk, L.M.F., Ferrara, M.A., Nepomuceno, A.L., Molinari, H.B C., Bon, E.P.S., 2010. Biomass residues in Brazil: availability and potential uses. Waste Biomass Valorization 1, 65-76. http://dx.doi.org/10.1007/s12649-0109008-8.

Fuess, L.T., Garcia, M.L., 2014. Implications of stillage land disposal: a critical review on the impacts of fertigation. J. Environ. Manage. 145, 210-229. http://dx.doi. org/10.1016/j.jenvman.2014.07.003.

Guiotoku, M., Hansel, F.A., Novotny, E.H., de Freitas Maia, C.M.B., 2012. Molecular and morphological characterization of hydrochar produced by microwaveassisted hydrothermal carbonization of cellulose. Pesqui. Agropecu. Bras. 47, 687-692. http://dx.doi.org/10.1590/S0100-204X2012000500008.

Heilmann, S.M., Molde, J.S., Timler, J.G., Wood, B.M., Mikula, A.L., Vozhdayev, G.V., Colosky, E.C., Spokas, K.A., Valentas, K.J., 2014. Phosphorus reclamation through hydrothermal carbonization of animal manures. Environ. Sci. Technol. 48, 10323-10329. http://dx.doi.org/10.1021/es501872k.

Hoekman, S.K., Broch, A., Robbins, C., Zielinska, B., Felix, L., 2013. Hydrothermal carbonization (HTC) of selected woody and herbaceous biomass feedstocks. Biomass Convers. Biorefinery 3, 113-126. http://dx.doi.org/10.1007/S13399012-0066-Y.

Hu, B., Wang, K., Wu, L., Yu, S.H., Antonietti, M., Titirici, M.M., 2010. Engineering carbon materials from the hydrothermal carbonization process of biomass. Adv. Mater. 22, 813-828. http://dx.doi.org/10.1002/adma.200902812.

IBI, 2015. Standardized product definition and product testing guidelines for biochar that is used in soil, v. 1.1. Int. Biochar Initiat. 1-47. doi:http://www. biochar-international.org/characterizationstandard. 22.

Kang, S., Li, X., Fan, J., Chang, J., 2012. Characterization of hydrochars produced by hydrothermal carbonization of lignin, cellulose, d-xylose, and wood meal. Ind Eng. Chem. Res. 51, 9023-9031. http://dx.doi.org/10.1021/ie300565d.

Kruse, A., Funke, A., Titirici, M.M., 2013. Hydrothermal conversion of biomass to fuels and energetic materials. Curr. Opin. Chem. Biol. 17, 515-521. http://dx.doi. org/10.1016/j.cbpa.2013.05.004

Libra, J.A., Ro, K.S., Kammann, C., Funke, A., Berge, N.D., Neubauer, Y., Titirici, M.-M., Fühner, C., Bens, O., Kern, J., Emmerich, K.-H., 2011. Hydrothermal carbonization of biomass residuals: a comparative review of the chemistry, processes and applications of wet and dry pyrolysis. Biofuels 2, 71-106. http://dx.doi.org/ 10.4155/bfs.10.81.

Linstrom, P.J., Mallard, W.G., 2014. NIST Chemistry webBook, NIST Standard Reference Database Number 69 [WWW Document]. Natl. Inst. Stand. Technol. doi: citeulike-article-id:3211271.

Loh, Y.R., Sujan, D., Rahman, M.E., Das, C.A., 2013. Review sugarcane bagasse - the future composite material: a literature review. Resour. Conserv. Recycl. 75, 1422. http://dx.doi.org/10.1016/j.resconrec.2013.03.002.

Lu, X., Pellechia, P.J., Flora, J.R.V., Berge, N.D., 2013. Influence of reaction time and temperature on product formation and characteristics associated with the hydrothermal carbonization of cellulose. Bioresour. Technol. 138, 180-190. http://dx.doi.org/10.1016/j.biortech.2013.03.163.

Lu, X., Flora, J.R.V., Berge, N.D., 2014. Influence of process water quality on hydrothermal carbonization of cellulose. Bioresour. Technol. 154, 229-239. http://dx.doi.org/10.1016/j.biortech.2013.11.069.

Lynam, J.G., Coronella, C.J., Yan, W., Reza, M.T., Vasquez, V.R., 2011. Acetic acid and lithium chloride effects on hydrothermal carbonization of lignocellulosic biomass. Bioresour. Technol. 102, 6192-6199. http://dx.doi.org/10.1016/j. biortech.2011.02.035.

Lyra, M.R.C.C., Rolim, M.M., Silva, J.A.A.Da., 2003. Toposseqüência de solos fertigados com vinhaça: contribuição para a qualidade das águas do lençol freático. Rev. Bras. Eng. Agrícola Ambient. 7, 525-532. http://dx.doi.org/10.1590/S141543662003000300020.

Makreski, P., Jovanovski, G., Dimitrovska, S., 2005. Minerals from Macedonia: XIV. Identification of some sulfate minerals by vibrational (infrared and Raman) spectroscopy. Vib. Spectrosc. 39, 229-239. http://dx.doi.org/10.1016/j. vibspec.2005.04.008.

Melo, C.A., Junior, F.H.S., Bisinoti, M.C., Moreira, A.B., Ferreira, O.P., 2016 Transforming sugarcane bagasse and vinasse wastes into hydrochar in the presence of phosphoric acid: an evaluation of nutrient contents and structural properties. Waste and Biomass Valorization. http://dx.doi.org/10.1007/s12649016-9664-4.

Moraes, B.S., Zaiat, M., Bonomi, A., 2015. Anaerobic digestion of vinasse from sugarcane ethanol production in Brazil: challenges and perspectives. Renewable Sustainable Energy Rev. 44, 888-903. http://dx.doi.org/10.1016/j. rser.2015.01.023.

Othman, I., Al-Masri, M.S., 2007. Impact of phosphate industry on the environment: a case study. Appl. Radiat. Isot. 65, 131-141.

Parshetti, G.K., Kent Hoekman, S., Balasubramanian, R., 2013. Chemical, structural and combustion characteristics of carbonaceous products obtained by hydrothermal carbonization of palm empty fruit bunches. Bioresour. Technol. 135, 683-689. http://dx.doi.org/10.1016/j.biortech.2012.09.042.

Pessoa-Jr, A., Roberto, I.C., Menossi, M., Santos, R.R., Ortega Filho, S., Penna, T.C.V., 2005. Perspectives on Bioenergy and Biotechnology in Brazil. Appl. Biochem. Biotechnol., 121-124

Reza, M.T., Lynam, J.G., Uddin, M.H., Coronella, C.J., 2013. Hydrothermal carbonization: fate of inorganics. Biomass Bioenergy 49, 86-94. http://dx.doi. org/10.1016/j.biombioe.2012.12.004. 
Reza, M.T., Nover, J., Wirth, B., J Coronella, C., 2016. Hydrothermal carbonization of glucose in saline solution: sequestration of nutrients on carbonaceous materials. AIMS Energy 4, 173-189. http://dx.doi.org/10.3934/ energy.2016.1.173.

Semerjian, L., Ayoub, G., 2003. High pH magnesium coagulation flocculation in wastewater treatment. Adv. Environ. Res. 7, 389-403.

Sevilla, M., Fuertes, A.B., 2009. The production of carbon materials by hydrothermal carbonization of cellulose. Carbon N. Y. 47, 2281-2289. http://dx.doi.org 10.1016/j.carbon.2009.04.026.

Sindhu, R., Gnansounou, E., Binod, P., Pandey, A., 2016. Bioconversion of sugarcane crop residue for value added products. Renewable Energy, 1-13.

Skoog, D.A., West, D.M., Holler, F.J., Crouch, S.R., 2004. Fundamentals of Analytical Chemistry. http://dx.doi.org/10.1007/s00216-010-3971-6.

Smith, A.M., Ross, A.B., 2016. Production of bio-coal, bio-methane and fertilizer from seaweed via hydrothermal carbonisation. Algal Res. 16, 1-11. http://dx.doi.org/ 10.1016/j.algal.2016.02.026.

Tekin, K., Karagöz, S., Bektaş, S., 2013. Hydrothermal conversion of woody biomass with disodium octaborate tetrahydrate and boric acid. Ind. Crops Prod. 49, 334 340. http://dx.doi.org/10.1016/j.indcrop.2013.05.014. van der Stelt, M.J.C., Gerhauser, H., Kiel, J.H.A., Ptasinski, K.J., 2011. Biomass upgrading by torrefaction for the production of biofuels: a review. Biomass Bioenergy 35, 3748-3762. http://dx.doi.org/10.1016/j.biombioe.2011.06.023.

Van Krevelen, D.W., 1984. Organic geochemistry-old and new. Org. Geochem. 6, 110. http://dx.doi.org/10.1016/0146-6380(84)90021-4.

Wiedner, K., Naisse, C., Rumpel, C., Pozzi, A., Wieczorek, P., Glaser, B., 2013. Chemical modification of biomass residues during hydrothermal carbonization - what makes the difference, temperature or feedstock? Org. Geochem. 54, 91100. http://dx.doi.org/10.1016/j.orggeochem.2012.10.006.

Wilkie, A.C., Riedesel, K.J., Owens, J.M., 2000. Stillage characterization and anaerobic treatment of ethanol stillage from conventional and cellulosic feedstocks. Biomass Bioenergy 19, 63-102. http://dx.doi.org/10.1016/S0961-9534(00) 00017-9.

Yu, G., Sun, B., Pei, Y., Xie, S., Yan, S., Qiao, M., Fan, K., Zhang, X., Zong, B., 2010. FexOy@C spheres as an excellent catalyst for Fischer-Tropsch synthesis. J. Am. Chem. Soc. 132, 935-937. http://dx.doi.org/10.1021/ja906370b.

Zhao, N., Wu, S., He, C., Wang, Z., Shi, C., Liu, E., Li, J., 2013. One-pot synthesis of uniform $\mathrm{Fe} 3 \mathrm{O} 4$ nanocrystals encapsulated in interconnected carbon nanospheres for superior lithium storage capability. Carbon N. Y. 57, 22812289. http://dx.doi.org/10.1016/j.carbon.2013.01.056. 